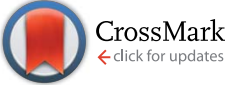

Cite this: RSC Adv., 2017, 7, 12391

\title{
Novel valproic aminophenol amides with enhanced glial cell viability effect $\uparrow$
}

\author{
Andrea Alpuche-García, Xochitl Dávila-González, Leticia Arregui* \\ and Hiram I. Beltrán*
}

New valproic acid derivatives were synthesized by coupling valproyl chloride with ortho-aminophenols, resulting in seven $\mathrm{N}$-(ortho-hydroxyphenyl)valproamides. These amides share similar structural characteristics and exhibit tuneable electronic and steric contributions either without particular substituents, or through the inclusion of electro-donating $(-\mathrm{Me})$, electro-withdrawing $\left(-\mathrm{NO}_{2}\right)$ or pi electro-donating/sigma electro-withdrawing $(-\mathrm{Cl})$ substituents at the aromatic ring. The identity of such derivatives was evidenced through spectroscopic characterization using FTIR, ${ }^{1} \mathrm{H},{ }^{13} \mathrm{C}$ and HETCOR NMR, as well as by analyzing their melting points. In particular, for three derivatives it was feasible to determine their chemical structures in the crystal phase; all three behaved in a similar fashion and exhibited very similar conformations independent of the attached substituents. The base compound was found to exhibit 15.8 times more activity in C6 cells and 4.4 times more activity in U373 cells compared with VPA. In general, the parent compound, or those having - Me as a substituent, presented a greater effect on C6 cells than U373 cells. However, those with $-\mathrm{NO}_{2}$ and $-\mathrm{Cl}$ substituents, as well as VPA, required similar doses for the $\mathrm{IC}_{50}$ in both cell lines. Modification of the base compound with a $-\mathrm{Me}$ or $-\mathrm{NO}_{2}$ substituent increased the effect on cell viability to ca. 20 times that of VPA in both C6 and U373, indicating that a larger structure causes an important enhancement in the inhibition of cell viability. In both cell lines, $-\mathrm{Cl}$ containing derivatives were the most active compounds. For these derivatives, an activity increase of ca. 59 and 47 times that of VPA was observed for C6 and U373 cells, respectively. An important perspective is that VPA analogues possessing an aromatic ring with a $-\mathrm{Cl}$ substituent may become central structures in the search for more potent pharmaceutical prototypes.

Received 3rd January 2017

Accepted 23rd January 2017

DOI: $10.1039 / c 7 r a 00048 k$

rsc.li/rsc-advances progression. VPA and other iHDAC have been explored for glioblastoma treatment alone or with chemotherapy or radiotherapy, and promising effects have been found. However, additional efforts to find more effective drugs are required, in particular those involving the testing of drugs in glioblastoma cell lines, given the previously reported evidence. ${ }^{8}$

In order to diminish or avoid the side effects associated with VPA, as well as to enhance its activity, a common and useful strategy has been the chemical modification of the parent compound. For instance, in 2005, Eyal et al. ${ }^{9}$ evaluated and compared the iHDAC of VPA and its constituent isomers, including valnoctic acid (VCA), propylisopropylacetic acid (PIA), diisopropylacetic acid (DIA), 2,2,3,3-tetramethylcyclopropylcarboxylic acid (TMCA), and VPA metabolites: 2-en-AVP and 4-en-AVP. The authors found that almost any chemical modification of the VPA structure results in the decay of its activity as iHDAC. Another strategy, developed in 2006 by Deubzer and co-workers, ${ }^{10}$ was the employment of VPA analogues with longer side chains, as well as the inclusion of alkenyl fragments in the structure. These changes caused multifunctional properties of such derivatives as iHDAC, showing interesting cell cycle modulation due to the induction
Departamento de Ciencias Naturales, DCNI, UAM Cuajimalpa, 05300, Ciudad de México, Mexico.E-mail: arregui@correo.cua.uam.mx; hbeltran@correo.cua.uam.mx $\dagger$ Electronic supplementary information (ESI) available: CCDC no. 1525302 for $\mathbf{V A}_{2}, 1525303$ for $\mathbf{V A}_{3}$, and 1525301 for $\mathbf{V A}_{\mathbf{6}}$. For ESI and crystallographic data in CIF or other electronic format see DOI: $10.1039 / \mathrm{c} 7 \mathrm{ra00048 \textrm {k }}$ 
of p21 expression, as well as low toxicity on CD34+ bone marrow cells. ${ }^{10}$ Another recent effort to enhance the beneficial effects of VPA derivatives was carried out using phosphovalproic acid, employed as iHDAC, which involved tracking its dominant molecular target STAT3. This compound includes ester functionality to anchor the VPA fragment to the diethyl (4hydroxybenzyl) phosphate parent compound. This compound has shown synergistic behaviour in enhanced pancreatic cancer inhibition, compared with VPA. ${ }^{11}$ Lastly, in 2009, the compound $N$-9-(2-hydroxy)ethoxymethylguanine disubstituted with VPA was patented $^{\mathbf{1 2}}$ and in 2014 it was evaluated by Tarasenko and coworkers $^{13}$ as an anticancer agent in various cell lines with promising results. In particular, ester and amide groups link this compound to the VPA moiety, indicating that these functionalities should work to generate new promising derivatives of VPA. Some other trials to find potent VPA analogues with enhanced iHDAC activity have also emerged lately. ${ }^{14}$

Thus, the current work aims to obtain and characterize seven new VPA derivatives, wherein the molecular design strategy is not to vary the valproic fragment, but instead the carboxylate moiety, through the formation of amidic functionalities. This change is accompanied by the inclusion of an aromatic ring containing different electro-withdrawing or electro-releasing substituents in order to modulate bioactivities. ${ }^{15}$ Finally, the new structures recover the $\mathrm{OH}$ fragment present in VPA, through the inclusion of a phenolic group. The results of this contribution are that the seven valproic amides exhibit an enhanced effect on cell viability compared with VPA in two glioma cell lines.

\section{Experimental section}

\section{General information}

Available solvents and reagents were used as received. 2-Propylpentanoic acid (VPA, CAT P6273-100ML), 2-amino- $p$-cresol (APh2, CAT 144908-50G), 2-amino-5-methyl-phenol (APh3, CAT 144916-10G), 2-amino-4-nitro-phenol (APh4, CAT A70402-5G), 2amino-5-nitro-phenol (APh5, CAT 303585-25G), 2-amino-4chloro-phenol (APh6, CAT C44400-100G) and 2-amino-5chloro-phenol (APh7, CAT 552224-25G) were acquired from Sigma-Aldrich; 2-aminophenol (APh1, CAT 09110-100G) was obtained from Fluka. The solvents employed were acetonitrile ( $\mathrm{CH}_{3} \mathrm{CN}$, CAT 9011-03-4L), tetrahydrofuran (THF, CAT 9450-03$4 \mathrm{~L}$ ), ethyl acetate (AcOEt, CAT 75-05-8-2L) and hexane (Hex, CAT 930L) and were acquired from Reasol.

\section{D \& 2D nuclear magnetic resonance spectroscopy (1D \& 2D NMR)}

NMR experiments were performed on a VARIAN Mercury 200-BB spectrometer and on an Anasazi spectrometer EFT-60. The ${ }^{1} \mathrm{H}$ and ${ }^{13} \mathrm{C}$ chemical shifts $[\delta=\mathrm{ppm}]$ were taken as relative to internal SiMe ${ }_{4}\left(\mathrm{TMS}, \delta\left({ }^{1} \mathrm{H}\right)=0.00 \mathrm{ppm}, \delta\left({ }^{13} \mathrm{C}\right)=0.00 \mathrm{ppm}\right)$, and the coupling constants were quoted in $\mathrm{Hz}$. The employed solvent was $\mathrm{CDCl}_{3}$, and just for the compounds AV4 and AV5, $0.1 \mathrm{~mL}$ of DMSO- $d_{6}$ was added to achieve full dissolution due to the presence of nitro groups.

\section{Fourier transform infrared (FT-IR) spectra}

The FT-IR spectra were recorded in the range of $4000-400 \mathrm{~cm}^{-1}$ on a Bruker Tensor-27 FT-IR spectrophotometer, using $\mathrm{KBr}$ pellets or $\mathrm{KBr}$ mixtures of each of the isolated samples. The samples were measured using the ATR technique.

\section{Single crystal X-ray diffraction (X-ray)}

X-ray diffraction data were acquired on an Enraf Nonius diffractometer FR590 Kappa-CCD $\left(\lambda_{\text {MoKa }}=0.71073 \AA\right.$, graphite monochromator, $T=293 \mathrm{~K}$, using rotating image scan with CCD). Monocrystals were mounted in LINDEMAN tubes. Reflections were corrected for Lorentz and polarization effects. The SHELX-S and SHELX-L 2014 program suite ${ }^{16}$ was used for the first structural solution, as well as for the refinement and output data. These programs, as well as the molecular perspectives, were employed and obtained in the OLEX2 environment. ${ }^{17}$ All heavy atoms were found through electronic density differences in the Fourier maps and refined anisotropically. Some of the hydrogen atoms were also found through Fourier maps and refined isotropically, and the remnants were geometrically calculated and added for the final refinement.

\section{Thin layer chromatography (TLC)}

Thin layer chromatography (TLC) aluminium sheet plates of silica $60 \mathrm{~F}_{254}$ of $0.2 \mathrm{~mm}$ width (Merck, $\mathrm{KGaA}$ ) were employed to track the course of each reaction. The TLC separation of each compound was developed using a hexane/ethyl acetate 1:1 solvent mixture and the plates were revealed using a UV-vis lamp. In all obtained VA products, the appearance of single spots was indicative of their purity and also confirmed that the desired reaction had been achieved.

\section{Synthetic methodology for compounds $\mathrm{VA}_{1-7}$}

Synthesis of $\mathbf{V A}_{1}$. In a round flask, $0.5 \mathrm{~g}(3.5 \mathrm{mmol})$ of VPA was poured and dissolved in $40 \mathrm{~mL}$ of $\mathrm{CH}_{3} \mathrm{CN}$. Then, $0.68 \mathrm{~mL}$ (3.5 mmol) of $\mathrm{SOCl}_{2}$ was added to yield the acid chloride of VPA in situ. ${ }^{18}$ This stage was carried out for $24 \mathrm{~h}$ at room temperature, keeping the system closed with a glass cap. Then $0.38 \mathrm{~g}$ (3.5 mmol) of APh1 was predissolved in $5 \mathrm{~mL}$ of $\mathrm{CH}_{3} \mathrm{CN}$ and 5 $\mathrm{mL}$ of triethylamine was added to the round flask drop by drop through an addition funnel, followed by magnetic stirring for an hour. The mixture was set to reflux at a temperature which was maintained for $24 \mathrm{~h}$ to finally yield the $N$-(2-hydroxyphenyl)2-propylpentanamide $\left(\mathbf{A V}_{\mathbf{1}}\right)$. The completion of the reaction was followed by FTIR carbonyl band displacement of the carboxylic acid, acyl chloride and finally secondary amide groups, as well as by thin layer chromatography of the reaction crudes. Volatiles were removed under reduced pressure, and $20 \mathrm{~mL}$ of THF was added to the remaining solids, thus keeping the triethylammonium chloride salt insoluble, which was separated through filtration. The soluble fraction was dried through reduced pressure distillation and the remnant solid was recrystallized in an ethyl acetate/hexane $1: 4$ solvent mixture. In this way it was feasible to obtain compound $\mathbf{V A}_{\mathbf{1}}$ in a yield of $64.8 \%$. Similar to $\mathbf{V A}_{\mathbf{1}}$, the other six valproic amides $\left(\mathbf{V A}_{2-7}\right)$ were 
prepared by just varying the corresponding ortho-aminophenol source. As stated in a very recent contribution, this synthetic strategy solely provided $\mathrm{N}$-acylation of the carboxylate moiety, instead of $\mathrm{O}$-acylation. ${ }^{19}$

$\mathrm{N}$-(2-Hydroxyphenyl)-2-propylpentanamide $\quad\left(\mathrm{VA}_{1}\right)$. Light brown solid, yield $64.8 \%$, mp $55-57{ }^{\circ} \mathrm{C}$. FTIR $\left(\nu=\mathrm{cm}^{-1}, \mathrm{KBr}\right)$ :

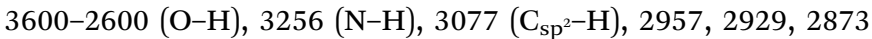
$\left(\mathrm{C}_{\mathrm{sp}^{3}}-\mathrm{H}\right), 1626,1603(-\mathrm{C}(=\mathrm{O})-\mathrm{N}-), 1545,1497(-\mathrm{C}(\mathrm{O})=\mathrm{N}-)$, 1387, 1313, 1264, 772, 750, 722, 693. ${ }^{1} \mathrm{H}$ NMR $\left(\delta=\right.$ ppm, $\mathrm{CDCl}_{3}, J$ $=\mathrm{Hz}): 8.95,8.73(\mathrm{OH}, \mathrm{sb}, 1 \mathrm{H} \& \mathrm{NH}, \mathrm{s}, 1 \mathrm{H}), 7.44\left(\mathrm{H} 3, \mathrm{~d}, J_{\mathrm{o}}=7.25\right.$, $1 \mathrm{H}), 7.02\left(\mathrm{H} 5, \mathrm{t}, J_{\mathrm{o}}=7.25,1 \mathrm{H}\right), 6.95\left(\mathrm{H} 4, \mathrm{t}, J_{\mathrm{o}}=7.25,1 \mathrm{H}\right), 6.83$ (H6, d, $\left.J_{\mathrm{o}}=7.25,1 \mathrm{H}\right), 2.46$ (H8, q, $\left.J=6.42,1 \mathrm{H}\right), 1.49$ (H9, m, $4 \mathrm{H}), 1.23(\mathrm{H} 10, \mathrm{~m}, 4 \mathrm{H}), 0.92(\mathrm{H} 11, \mathrm{t}, J=6.42,6 \mathrm{H}) .{ }^{13} \mathrm{C} \mathrm{NMR}(\delta$ $=$ ppm, $\left.\mathrm{CDCl}_{3}\right): 177.3(\mathrm{C} 7,1 \mathrm{C}), 148.2(\mathrm{C} 1,1 \mathrm{C}), 126.5(\mathrm{C} 2,1 \mathrm{C})$, 126.0 (C5, 1C), 122.4 (C4, 1C), 120.4 (C3, 1C), 118.4 (C6, 1C), 48.0 (C8, 1C), 35.4 (C9, 2C), 20.8 (C10, 2C), 14.1 (C11, 2C).

$\mathbf{N}$-(2-Hydroxy-5-methylphenyl)-2-propylpentanamide ( $\left.\mathbf{V A}_{2}\right)$. Dark brown solid, yield 95.7\%, mp 99-101 ${ }^{\circ} \mathrm{C}$. FTIR $\left(\nu=\mathrm{cm}^{-1}\right.$, $\mathrm{KBr})$ : 3580-2400 (O-H), $3252(\mathrm{~N}-\mathrm{H}), 3221,3033\left(\mathrm{C}_{\mathrm{sp}^{2}}-\mathrm{H}\right), 2957$, 2927, 2872, $2861\left(\mathrm{C}_{\mathrm{sp}^{3}}-\mathrm{H}\right), 2660,2341,1630,1605(-\mathrm{C}(=\mathrm{O})-\mathrm{N}-)$ 1541, $1507(-\mathrm{C}(\mathrm{O})=\mathrm{N}-), 1358,1317,1267,1259,1034,1015,949$, $868,821,780,766,727,713 . \mathrm{NMR}^{1} \mathrm{H}\left(\delta=\mathrm{ppm}, \mathrm{CDCl}_{3}, J=\mathrm{Hz}\right)$ : 9.20, $8.94(\mathrm{OH}, \mathrm{sb}, 1 \mathrm{H} \& \mathrm{NH}, \mathrm{s}, 1 \mathrm{H}), 7.37$ (H3, s, 1H), 6.83-6.81 (H5, H6, m, 2H), 2.48 (H8, q, $J=7.3,1 \mathrm{H}), 2.24(\mathrm{H} 12, \mathrm{~s}, 3 \mathrm{H}), 1.55$ (H9, m, 4H), 1.36 (H10, m, 4H), 0.92 (H11, t, $J=7.3,6 \mathrm{H})$. NMR ${ }^{13} \mathrm{C}\left(\delta=\mathrm{ppm}, \mathrm{CDCl}_{3}\right): 175.9(\mathrm{C} 7,1 \mathrm{C}), 145.5(\mathrm{C} 1,1 \mathrm{C}), 128.8(\mathrm{C} 4$, 1C), 125.8 (C2, 1C), 125.8 (C5, 1C), 122.0 (C3, 1C), 117.2 (C6, 1C), 47.3 (C8, 1C), 35.2 (C9, 2C), 20.5 (C10, 2C), 20.4 (C12, 1C), 15.9 (C11, 2C). Suitable monocrystals for the X-ray diffraction analysis were obtained in a $4: 1$ hexane/ethyl acetate solvent mixture.

$\mathbf{N}$-(2-Hydroxy-4-methylphenyl)-2-propylpentanamide $\quad\left(\mathrm{VA}_{3}\right)$. Light brown solid, yield $92.7 \%, \mathrm{mp} 68-70{ }^{\circ} \mathrm{C}$. FTIR $\left(\nu=\mathrm{cm}^{-1}\right.$, $\mathrm{KBr})$ : 3700-2600 (O-H), $3238(\mathrm{~N}-\mathrm{H}), 3202,3046\left(\mathrm{C}_{\mathrm{sp}^{2}}-\mathrm{H}\right), 2959$, 2929, 2875, $2858\left(\mathrm{C}_{\mathrm{sp}^{3}}-\mathrm{H}\right), 1639,1611(-\mathrm{C}(=\mathrm{O})-\mathrm{N}-), 1598,1546$, $1510(-\mathrm{C}(\mathrm{O})=\mathrm{N}-), 1469,1459,1322,943,897,872,815,796,771$, 760, 733. $\mathrm{NMR}^{1} \mathrm{H}\left(\delta=\mathrm{ppm}, \mathrm{CDCl}_{3}, J=\mathrm{Hz}\right): 8.90,8.45(\mathrm{OH}, \mathrm{sb}$, $1 \mathrm{H} \& \mathrm{NH}, \mathrm{s}, 1 \mathrm{H}), 7.16\left(\mathrm{H} 3, \mathrm{~d}, J_{\mathrm{o}}=7.02,1 \mathrm{H}\right), 6.82(\mathrm{H} 6, \mathrm{~s}, 1 \mathrm{H}), 6.65$ (H4, d, $\left.J_{\mathrm{o}}=7.02,1 \mathrm{H}\right), 2.49$ (H8, q, $\left.J=6.72,1 \mathrm{H}\right), 2.27$ (H12, s, $3 \mathrm{H}), 1.48$ (H9, m, 4H), 1.29 (H10, m, 4H), 0.92 (H11, t $J=6.72$, $6 \mathrm{H}) . \mathrm{NMR}^{13} \mathrm{C}\left(\delta=\mathrm{ppm}, \mathrm{CDCl}_{3}\right): 177.0(\mathrm{C} 7,1 \mathrm{C}), 148.4(\mathrm{C} 1,1 \mathrm{C})$, 136.9 (C5, 1C), 123.4 (C2, 1C), 122.3 (C3, 1C), 121.1 (C4, 1C), 119.4 (C6, 1C), 47.9 (C8, 1C), 35.4 (C9, 2C), 20.8 (C12, 1C), 20.0 (C10, 2C), 14.2 (C11, 2C). Suitable monocrystals for the X-ray diffraction analysis were obtained in a $4: 1$ hexane/ethyl acetate solvent mixture.

$\boldsymbol{N}$-(2-Hydroxy-5-nitrophenyl)-2-propylpentanamide $\quad$ (VA $\left._{4}\right)$. Light yellow solid, yield $24.6 \%$, mp 85-87 ${ }^{\circ} \mathrm{C}$. FTIR $\left(\nu=\mathrm{cm}^{-1}\right.$, $\mathrm{KBr})$ : 3500-2400 (O-H), $3416(\mathrm{~N}-\mathrm{H}), 3097\left(\mathrm{C}_{\mathrm{sp}^{2}}-\mathrm{H}\right), 2957,2937$, $2872\left(\mathrm{C}_{\mathrm{sp}^{3}-\mathrm{H}}\right), 2362,2344,1627,1595(-\mathrm{C}(=\mathrm{O})-\mathrm{N}-), 1539,1503$ $(-\mathrm{C}(\mathrm{O})=\mathrm{N}-), 1465,1461,1427,1400,1341(-\mathrm{N}(=\mathrm{O})-\mathrm{O}), 1327$, $1268,1244,1197,1167,1153,993,878,819,781,743 . \mathrm{NMR}^{1} \mathrm{H}(\delta$ $=$ ppm, $\left.\mathrm{CDCl}_{3}, J=\mathrm{Hz}\right): 9.22,8.86\left(\mathrm{OH}, \mathrm{sb}, 1 \mathrm{H} \& \mathrm{H} 3, \mathrm{~d}, J_{\mathrm{m}}=2.74\right.$, $1 \mathrm{H}), 8.82(\mathrm{NH}, \mathrm{s}, 1 \mathrm{H}), 7.88\left(\mathrm{H} 5, \mathrm{dd}, J_{\mathrm{o}}=8.96, J_{\mathrm{m}}=2.74,1 \mathrm{H}\right), 6.98$ $\left(\mathrm{H} 6, \mathrm{~d}, J_{\mathrm{o}}=8.96,1 \mathrm{H}\right), 2.52(\mathrm{H} 8, \mathrm{q}, J=7.14,1 \mathrm{H}), 1.50(\mathrm{H} 9, \mathrm{~m}$, $4 \mathrm{H}), 1.38(\mathrm{H} 10, \mathrm{~m}, 4 \mathrm{H}), 0.92(\mathrm{H} 11, \mathrm{t}, J=7.14,6 \mathrm{H}) . \mathrm{NMR}{ }^{13} \mathrm{C}(\delta$ $=$ ppm, $\left.\mathrm{CDCl}_{3}\right)$ : 176.3 (C7, 1C), 153.4 (C1, 1C), 140.2 (C4, 1C),
126.7 (C2, 1C), 120.8 (C5, 1C), 116.8 (C3, 1C), 116.0 (C6, 1C), 47.8 (C8, 1C), 35.1 (C9, 2C), 20.6 (C10, C2), 14.0 (C11, 2C).

$\boldsymbol{N}$-(2-Hydroxy-4-nitrophenyl)-2-propylpentanamide ( $\left.\mathbf{V A}_{5}\right)$. Orange solid, yield $30.6 \%, \mathrm{mp} 161-163{ }^{\circ} \mathrm{C}$. FTIR $\left(\nu=\mathrm{cm}^{-1}\right.$, $\mathrm{KBr})$ : 3600-2400 (O-H), $3408(\mathrm{~N}-\mathrm{H}), 3096\left(\mathrm{C}_{\mathrm{sp}^{2}}-\mathrm{H}\right), 2957,2934$, $2872\left(\mathrm{C}_{\mathrm{sp}^{3}} \mathrm{H}\right), 2362,2347,1669,1627(-\mathrm{C}(=\mathrm{O})-\mathrm{N}-), 1592,1506$ $(-\mathrm{C}(\mathrm{O})=\mathrm{N}-), 1465,1424,1400,1346(-\mathrm{N}(=\mathrm{O})-\mathrm{O}), 1327,1268$, $1247,1194,896,875,825,880,743 . \mathrm{NMR}^{1} \mathrm{H}\left(\delta=\mathrm{ppm}, \mathrm{CDCl}_{3}, J\right.$ $=\mathrm{Hz})$ : 9.07, $8.35(\mathrm{OH}, \mathrm{sb}, 1 \mathrm{H} \& \mathrm{NH}, \mathrm{s}, 1 \mathrm{H}), 8.20\left(\mathrm{H} 3, \mathrm{~d}, J_{\mathrm{o}}=8.88\right.$, $1 \mathrm{H}), 7.76\left(\mathrm{H} 4, \mathrm{~d}, J_{\mathrm{o}}=8.88,1 \mathrm{H}\right), 7.63(\mathrm{H} 6, \mathrm{~s}, 1 \mathrm{H}), 2.43(\mathrm{H} 8, \mathrm{q}, J=$ 7.14, 1H), $1.48(\mathrm{H} 9, \mathrm{~m}, 4 \mathrm{H}), 1.36(\mathrm{H} 2, \mathrm{~m}, 4 \mathrm{H}), 0.92(\mathrm{H} 11, \mathrm{t}, J=$ 7.14, 6H). $\mathrm{NMR}^{13} \mathrm{C}\left(\delta=\mathrm{ppm}, \mathrm{CDCl}_{3}\right): 175.0(\mathrm{C} 7,1 \mathrm{C}), 146.1$ (C1, 1C), 142.5 (C5, 1C), 132.6 (C2, 1C), 118.7 (C3, 1C), 114.7 (C4, 1C), 109.5 (C6, 1C), 47.1 (C8, 1C), 34.5 (C9, 2C), 19.9 (C10, C2), 13.4 (C11, 2C).

$\boldsymbol{N}$-(2-Hydroxy-5-chlorophenyl)-2-propylpentanamide $\quad\left(\mathrm{VA}_{\mathbf{6}}\right)$. Dark brown solid, yield $42.4 \%, \mathrm{mp} 90-92{ }^{\circ} \mathrm{C}$. FTIR $\left(\nu=\mathrm{cm}^{-1}\right.$, $\mathrm{KBr})$ : 3650-2400 (O-H), $3251(\mathrm{~N}-\mathrm{H}), 3185\left(\mathrm{C}_{\mathrm{sp}^{2}}-\mathrm{H}\right), 2958,2932$, $2876\left(\mathrm{C}_{\mathrm{sp}^{3}-\mathrm{H}}\right), 1630,1593(-\mathrm{C}(=\mathrm{O})-\mathrm{N}-), 1541,1524(-\mathrm{C}(\mathrm{O})=\mathrm{N}-)$, 1291, 867, $821(\mathrm{C}-\mathrm{Cl})$. NMR ${ }^{1} \mathrm{H}\left(\delta=\mathrm{ppm}, \mathrm{CDCl}_{3}\right): 8.17,7.86$ (OH, s, 1H \& NH, s, 1H), 7.40 (H3, s, 1H), 6.95 (H5, d, 1H), 6.95 (H6, d, 1H), 2.35 (H8, q, $J=6.60,1 \mathrm{H}), 1.45$ (H9, m, 4H), 1.20 $(\mathrm{H} 10, \mathrm{~m}, 4 \mathrm{H}), 0.92(\mathrm{H} 11, \mathrm{t}, J=6.60,6 \mathrm{H}) . \mathrm{NMR}{ }^{13} \mathrm{C}(\delta=\mathrm{ppm}$, $\left.\mathrm{CDCl}_{3}\right): 177.3(\mathrm{C} 7,1 \mathrm{C}), 147.0(\mathrm{C} 1,1 \mathrm{C}), 127.0(\mathrm{C} 5,1 \mathrm{C}), 126.3(\mathrm{C} 2$, 1C), 125.0 (C4, 1C), 121.9 (C3, 1C), 119.5 (C6, 1C), 48.3 (C8, 1C), 35.5 (C9, 2C), 21.0 (C10, C2), 14.2 (C11, 2C). Suitable monocrystals for the X-ray diffraction analysis were obtained in a $4: 1$ hexane/ethyl acetate solvent mixture.

$\boldsymbol{N}$-(2-Hydroxy-4-chlorophenyl)-2-propylpentanamide (VA $)$. Light brown solid, yield $35.7 \%$, mp 125-127 ${ }^{\circ} \mathrm{C}$. FTIR $\left(\nu=\mathrm{cm}^{-1}\right.$, $\mathrm{KBr})$ : 3560-2600 (O-H), $3297(\mathrm{~N}-\mathrm{H}), 3186\left(\mathrm{C}_{\mathrm{sp}^{2}}-\mathrm{H}\right), 2958,2935$, $2867\left(\mathrm{C}_{\mathrm{sp}^{3}}-\mathrm{H}\right), 1633,1593(-\mathrm{C}(=\mathrm{O})-\mathrm{N}-), 1531,1495(-\mathrm{C}(\mathrm{O})=\mathrm{N}-)$ 919, 896, $807(\mathrm{C}-\mathrm{Cl}) . \mathrm{NMR}^{1} \mathrm{H}\left(\delta=\mathrm{ppm}, \mathrm{CDCl}_{3}, J=\mathrm{Hz}\right)$ : 8.50, $7.95(\mathrm{OH}, \mathrm{s}, 1 \mathrm{H} \& \mathrm{NH}, \mathrm{s}, 1 \mathrm{H}), 7.18\left(\mathrm{H} 3, \mathrm{~d}, J_{\mathrm{o}}=8.40,1 \mathrm{H}\right), 7.00$ $\left(\mathrm{H} 6, \mathrm{~d}, J_{\mathrm{m}}=2.04,1 \mathrm{H}\right), 6.80\left(\mathrm{H} 4, \mathrm{dd}, J_{\mathrm{o}}=8.40, J_{\mathrm{m}}=2.04,1 \mathrm{H}\right)$, 2.36 (H8, q, $J=6.60,1 \mathrm{H}), 1.47$ (H9, m, 4H), 1.37 (H10, m, 4H), $0.92(\mathrm{H} 11, \mathrm{t}, J=6.60,6 \mathrm{H}) . \mathrm{NMR}^{13} \mathrm{C}\left(\delta=\mathrm{ppm}, \mathrm{CDCl}_{3}\right): 177.4(\mathrm{C} 7$, 1C), 149.1 (C1, 1C), 131.9 (C5, 1C), 124.8 (C2, 1C), 123.1 (C3, 1C), 120.6 (C4, 1C), 119.3 (C6, 1C), 48.4 (C8, 1C), 35.5 (C9, 2C), 21.0 (C10, C2), 14.3 (C11, 2C).

\section{Semiempirical determination of partition coefficient $(\log P)$}

A partition coefficient $(\log P)$ calculation was developed in Hyperchem v.8.0 computational chemistry software. This was performed for VPA and $\mathbf{V A}_{\mathbf{1}-7}$, starting from the X-ray structures obtained herein and through the replacement of particular functional groups and substituents for the whole series. Minimization was carried out with the PM3 semiempirical approach for these means and $\log P$ was computed for each compound at this level of theory.

\section{Cell culture and drug treatment}

Human U373 and rat C6 cells were cultured in Dulbecco's Modified Eagle's F12 Medium (DMEM-F12, Gibco, Thermo Fisher Scientific) with $10 \%$ fetal calf serum and $1 \%$ penicillin/ streptomycin in a humidified atmosphere containing $5 \% \mathrm{CO}_{2}$ 
at $37{ }^{\circ} \mathrm{C}$. Due to drug hydrophobicity, the drug stocks were dissolved in Tween 80 (1: 80 weight ratio) and then in DMSO $(1: 11 \mathrm{v} / \mathrm{v})$. C6 and U373 cells were generously donated by Drs José Segovia and José Antonio Arias-Montaño, both from CINVESTAV México.

\section{Cell viability}

The cells were seeded at a density of 15625 cells per $\mathrm{cm}^{2}$ in a 96 well plate. The C6 cells were treated for $24 \mathrm{~h}$ with the drugs at different concentrations, while the U373 cells were treated for $48 \mathrm{~h}$. Viability was determined using WST-1 reagent (Roche) and the absorbance was measured at $440 \mathrm{~nm}$ in a plate reader (Infinite M1000, Tecan). The cell viability was used to obtain the inhibitory concentration at $50 \%\left(\mathrm{IC}_{50}\right)$ of the tested compounds in the C6 and U373 cells. At least three independent assays were performed, and in each assay triplicates were included. The $\mathrm{IC}_{50}$ determination was done by non-linear logarithmic curve fitting using GraphPad Prism version 6.00 for Windows (GraphPad Software, La Jolla California USA, http://www.graphpad.com).

\section{Statistical analysis}

One-way ANOVA, followed by Dunnett's multiple comparisons test were performed also using GraphPad Prism v. 6.00.

\section{Results and discussion}

\section{Synthetic proposal for valproic amides (VA)}

In this research, the molecular modifications performed on the VPA parent were aimed on the acidic side, maintaining the valproyl moiety in an attempt to preserve the VPA biological activity. This is because acidic side modifications have been shown to cause a variety of effects that enhance the therapeutic capacity of VPA, e.g., the simplest VPA amide, valproyl amide (VA), which despite having antiepileptic activity has been demonstrated to lack iHDAC activity. ${ }^{20}$ Consequently, the exchange between acidic and amidic functionalities is not enough to produce the desired effect or even maintain it, because the iHDAC activity is suppressed for VA. Anyway, the preparation of other valproic amides is forthcoming, with the aim of preserving iHDAC activity as well as other particular biological properties like cell viability.

A common strategy in pharmaceutical design has been the inclusion of aminophenols to generate an amidic functionality, where the nitrogen atom forms a peptidic bond or derived groups, in order to form new chemical chimeras through molecular design. ${ }^{21}$ For example, in 2011, Yamazaki et al. ${ }^{22}$ patented a benzoxazole generated through aminophenols and intermediary amides. Their invention refers to a pharmaceutical composition containing this active ingredient to treat illnesses such as hyperlipidemia, atherosclerosis, diabetes and complications, inflammation, and heart disease. Another example, patented in 2013 by Casado-Centellas et al. ${ }^{23}$ is a catechol-O-methyltransferase inhibitor (iCOMT) that again is a benzoxazole derived from aminophenols and intermediary amides, employed in the prevention and treatment of amyloidosis. Moreover, one of the most commonly employed drugs is paracetamol or acetaminophen (APAP), which has analgesic properties and a chemical structure that contains a para-aminophenol moiety and an acetyl group attached as an amide to the aromatic ring. ${ }^{24}$ Considering the latter, it is evident that the incorporation of fragments such as aminophenols in diverse structures provides special characteristics in drugs and prototypes, thus signifying a promising way to design new VPA derivatives.

\section{Molecular design of VPA analogues of valproic amide (VA) containing aminophenols}

If one considers the use of aminophenols to generate an amidic functionality, the nitrogen atom is employed for the peptidic bond, leaving the $\mathrm{OH}$ untouched and thus recovering this group that is present in the VPA. The incorporation of $\mathrm{OH}$ should be as close as possible to the amide functional group, and the orthoaminophenol (OAMPOH) would provide this requisite, thus generating the desired parent compound that connects VPA with OAMPOH. With the inclusion of an aromatic ring in $\mathrm{OAMPOH}$, it is also possible to include structural modifications with substituents that are electro-donating or electrowithdrawing in nature, in order to modulate a plausible biological response and determine what substitution enhanced the activity. ${ }^{25}$ These variations include fragments with a slight effect on electronic density $(-\mathrm{H})$, electro-donating methyl $(-\mathrm{Me})$, electro-withdrawing nitro $\left(-\mathrm{NO}_{2}\right)$ and chlorine $(-\mathrm{Cl})$, which has an electro-withdrawing nature but also has the capacity for pi retrodonation to the aromatic ring.

\section{Synthesis of $\mathrm{VA}_{1-7}$}

To obtain the designed compounds, VPA was reacted with $\mathrm{SOCl}_{2}$ in a $1: 1$ ratio in acetonitrile to yield valproyl chloride ( $\mathrm{VPCl}$ ), which was reacted again to achieve amide formation. ${ }^{18}$ Once the VPCl was formed, the corresponding $\mathrm{OAMPOH}_{1-7}$ was added to form a 1:4 mixture with triethylamine to neutralize the hydrochloric acid obtained during both synthetic steps. In this way, it was possible to generate the amidic bond that joined VPA with $\mathrm{oAMPOH}_{1-7}$ to obtain seven $N$-(2-hydroxyphenyl)-

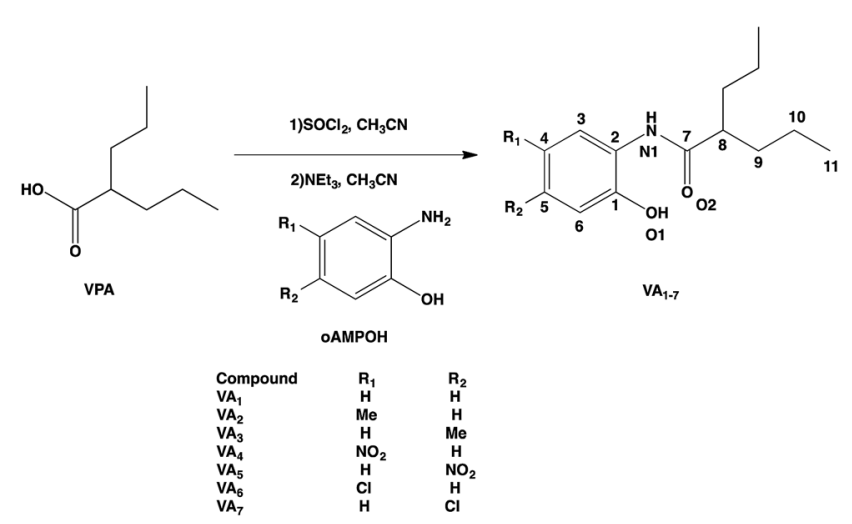

Scheme 1 Synthetic procedure for obtaining $\mathrm{VA}_{1-7}$. The numbering scheme employed was followed for the NMR and X-ray characterization. 
valproamides ( $\left.\mathbf{V A}_{\mathbf{1 - 7}}\right)$ (Scheme 1) in yields of 24.6-95.7\%. In all cases, the completion of the reaction was followed by FTIR analysis, due to the change of the carbonyl band from acid to valproyl chloride and finally to valproyl amide. Thin layer chromatography of the crude products was also performed. All compounds were characterized using FTIR, ${ }^{1} \mathrm{H},{ }^{13} \mathrm{C}$ and HETCOR NMR, and melting point analysis. Also, $\mathbf{V A}_{\mathbf{2}}, \mathbf{V A}_{\mathbf{3}}$ and $\mathbf{V A}_{\mathbf{6}}$ were characterized by their single crystal $\mathrm{X}$-ray diffraction structures.

\section{Spectroscopic and structural analysis of $\mathbf{V A}_{1-7}$}

In this section, the experimental and spectroscopic evidence for the obtained VA type compounds through Fourier transform infrared (FTIR) spectroscopy is presented. For the case of $\mathbf{V A}_{\mathbf{1}}$, a single band at $3256 \mathrm{~cm}^{-1}$ is characteristic of the $\mathrm{N}-\mathrm{H}$ bond present in a secondary amide $(\mathrm{R}-\mathrm{NH}-\mathrm{C}=\mathrm{O})$. A very broad band is observed around $3600-2600 \mathrm{~cm}^{-1}$, which is characteristic of a phenolic $\mathrm{O}-\mathrm{H}$ bond. A band belonging to $\mathrm{C}_{\mathrm{sp}^{2}}-\mathrm{H}$ from an aromatic ring at $3077 \mathrm{~cm}^{-1}$ and bands due to $\mathrm{C}_{\mathrm{sp}^{3-}} \mathrm{H}$ at 2957 , 2929 and $2873 \mathrm{~cm}^{-1}$ belonging to the valproyl moiety were identified. The bands of the amidic group appear doubled, and could be due to two possibilities of conformers. These bands appear since the amide and phenolic $\mathrm{OH}$ interact, (a) $\mathrm{Ph}-\underline{\mathrm{OH} \cdots \mathrm{O}}=\mathrm{C}-\mathrm{NH}$ and (b) $\mathrm{Ph}-(\mathrm{H}) \underline{\mathrm{O} \cdots \mathrm{H}-\mathrm{N}}-\mathrm{C}=\mathrm{O}$, gives four amidic bands in 1626, 1603, 1545 and $1497 \mathrm{~cm}^{-1}$. Analogously to $\mathbf{V A}_{\mathbf{1}}$, the FTIR band assignment was done for the remaining $N$-(2-hydroxyphenyl)-valproamides $\left(\mathbf{V A}_{2-7}\right)$. For $\mathbf{V A}_{\mathbf{4}}$ and $\mathbf{V} \mathbf{A}_{5}$, there were also $\mathrm{NO}_{2}$ bands at 1400 and $1341-1346 \mathrm{~cm}^{-1}$. Finally, the $\mathrm{C}-\mathrm{Cl}$ bands appear at around 867 and $821 \mathrm{~cm}^{-1}$ for $\mathbf{V A}_{6}$, and

Table $1{ }^{1} \mathrm{H}$ NMR of compounds $\mathrm{VA}_{1-7}{ }^{a}$

\begin{tabular}{llllllllllll}
\hline Cmpd & OH & \multirow{2}{*}{$\mathrm{NH}$} & $\mathrm{H} 3$ & \multirow{2}{*}{ H4 } & H5 & H6 & H8 & H9 & H10 & H11 & H12 \\
\hline VA $_{1}$ & 8.95 & 8.73 & 7.44 & 6.95 & 7.02 & 6.83 & 2.46 & 1.49 & 1.23 & 0.92 & - \\
VA $_{2}$ & 9.20 & 8.94 & 7.37 & - & 6.83 & 6.81 & 2.48 & 1.55 & 1.36 & 0.92 & 2.24 \\
VA $_{3}$ & 8.90 & 8.45 & 7.16 & 6.72 & - & 6.72 & 2.49 & 1.48 & 1.29 & 0.92 & 2.27 \\
VA $_{4}$ & 9.22 & 8.82 & 8.86 & - & 7.88 & 6.98 & 2.52 & 1.50 & 1.38 & 0.92 & - \\
VA $_{5}$ & 9.07 & 8.35 & 8.20 & 7.76 & - & 7.63 & 2.43 & 1.48 & 1.36 & 0.92 & - \\
VA $_{6}$ & 8.17 & 7.86 & 7.40 & - & 6.95 & 6.95 & 2.35 & 1.45 & 1.20 & 0.92 & - \\
VA $_{7}$ & 8.50 & 7.95 & 7.18 & 6.80 & - & 7.00 & 2.36 & 1.47 & 1.37 & 0.92 & -
\end{tabular}

${ }^{a}$ The numbering employed is shown in Scheme 1. Samples were dissolved in DMSO- $d_{6} . \delta=$ ppm.
896 and $807 \mathrm{~cm}^{-1}$ for $\mathbf{V A}_{7}$ (see Experimental section for further details).

Compounds $\mathbf{V A}_{1-7}$ were also characterized using ${ }^{1} \mathrm{H}$ (Table 1), ${ }^{13} \mathrm{C}$ (Table 2) and HETCOR $\left({ }^{13} \mathrm{C}-{ }^{1} \mathrm{H}\right)$ NMR experiments. Multiplicities resulted according to their substitution patterns. The HETCOR spectra results were very useful to ascertain the unequivocal assignment of resonances in $\mathbf{V A}_{\mathbf{1}-7}$, both for the ${ }^{1} \mathrm{H}$ and ${ }^{13} \mathrm{C}$ spectra. Quaternary carbons, secondary amide and phenol signals were confirmed as not having correlations in the HETCOR experiments. Protons H8, H9, H10 and H11, which belong to the valproyl moiety, appear in the ranges of 2.52-2.35 (H8), 1.55-1.45 (H9), 1.38-1.20 (H10) and $0.92 \mathrm{ppm}$ (H11), these resonances are slightly influenced by the function of distance among aromatic and valproyl fragments as well as by the particular substituents at the aromatic ring. In the case of ${ }^{13} \mathrm{C}$ NMR, the carbonyl signal C7 appears at 177.4-175.0 ppm, characteristic of a secondary amide with a double hydrocarbon chain, and is slightly influenced by aromatic substitution. In the case of $\mathrm{C} 1$, ipso to $\mathrm{OH}$, the peak appears in the range of 153.4$145.5 \mathrm{ppm}$, clearly evidencing the para electro-withdrawing effect of the $-\mathrm{NO}_{2}$ substituent in $\mathbf{V A}_{4}$, as well as the $-\mathrm{Cl}$ substituent for $\mathbf{V A}_{7}$, which is instead in the meta position. The C2 position, which is ipso to the amide, appears at 132.6$123.4 \mathrm{ppm}$, and is mostly affected by the para $-\mathrm{NO}_{2}$ in $\mathbf{V A}_{5}$. The remnant C3, C4, C5 and C6 positions appear at 123.1-116.8, 140.2-114.4, 142.5-120.8, and 119.5-109.5 ppm, respectively.

Moreover, out of the seven synthesized VA compounds, suitable monocrystals for three of them were obtained from ethyl acetate/hexane solvent mixtures. These cases were (crystalline systems and space groups) VA $\mathbf{A}_{3}$ (orthorhombic: $P 2_{1} 2_{1} 2_{1}$ ), $\mathbf{V A}_{2}$ and $\mathbf{V A}_{\mathbf{6}}$ (both as monoclinic: $P 2_{1} / c$ ), for which crystallographic data were determined through single crystal X-ray diffraction and analysis. Refined data and structures are presented in Tables 3 and 4. Fig. 1 shows the molecular perspectives following the same numbering as that used in the spectroscopic assignment. Selected structural parameters are shown in Table 4. These are aimed to analyse the amidic junction between VPA and OAMPOH, including bond distances $(\AA)$, bond angles $\left(^{\circ}\right.$ ) and dihedral angles $\left(^{\circ}\right)$ for these three analogous structures $\mathbf{V A}_{2}, \mathbf{V A}_{\mathbf{3}}$ and $\mathbf{V A}_{\mathbf{6}}$ (for which data will appear in this same order in this section). A very important observation is that aside from the attached substituent, these three amides are very similar in conformation. This behaviour clearly indicates a structural consensus depending on the

Table $2{ }^{13} \mathrm{C}$ NMR of compounds $\mathrm{VA}_{1-7}{ }^{a}$

\begin{tabular}{|c|c|c|c|c|c|c|c|c|c|c|c|c|}
\hline Cmpd & $\mathrm{C} 1$ & $\mathrm{C} 2$ & C3 & $\mathrm{C} 4$ & C5 & C6 & $\mathrm{C} 7$ & C8 & C9 & C10 & C11 & C12 \\
\hline $\mathbf{V A}_{1}$ & 148.2 & 126.5 & 120.4 & 122.4 & 126.0 & 118.4 & 177.3 & 48.0 & 35.4 & 20.8 & 14.1 & - \\
\hline $\mathbf{V A}_{2}$ & 145.5 & 125.8 & 122.0 & 128.8 & 125.8 & 117.2 & 175.9 & 47.3 & 35.2 & 20.5 & 13.9 & 20.4 \\
\hline $\mathrm{VA}_{4}$ & 153.4 & 126.7 & 116.8 & 140.2 & 120.8 & 116.0 & 176.3 & 47.8 & 35.1 & 20.6 & 14.0 & - \\
\hline $\mathrm{VA}_{5}$ & 146.1 & 132.6 & 118.7 & 114.7 & 142.5 & 109.5 & 175.0 & 47.1 & 34.5 & 19.9 & 13.4 & - \\
\hline $\mathrm{VA}_{6}$ & 147.0 & 126.3 & 121.4 & 125.0 & 127.0 & 119.5 & 177.3 & 48.3 & 35.5 & 21.0 & 14.2 & - \\
\hline
\end{tabular}

${ }^{a}$ The numbering employed is shown in Scheme 1 . Samples were dissolved in DMSO- $d_{6} . \delta=$ ppm. 
Table 3 Crystallographic data for compounds $\mathrm{VA}_{2}, \mathrm{VA}_{3}$ and $\mathrm{VA}_{6}{ }^{a}$

\begin{tabular}{|c|c|c|c|}
\hline Compound & $\mathbf{V A}_{2}$ & $\mathbf{V A}_{3}$ & $\mathbf{V A}_{6}$ \\
\hline Molecular formula & $\mathrm{C}_{15} \mathrm{H}_{23} \mathrm{NO}_{2}$ & $\mathrm{C}_{15} \mathrm{H}_{23} \mathrm{NO}_{2}$ & $\mathrm{C}_{14} \mathrm{H}_{20} \mathrm{ClNO}_{2}$ \\
\hline $\begin{array}{l}\text { Molecular } \\
\text { weight }\left[\mathrm{g} \mathrm{mol}^{-1}\right]\end{array}$ & 249.34 & 249.34 & 269.76 \\
\hline Crystalline system & Monoclinic & Orthorhombic & Monoclinic \\
\hline Space group & $P 2_{1} / c$ & $P 2_{1} 2_{1} 2_{1}$ & $P 2_{1} / c$ \\
\hline \multicolumn{4}{|l|}{ Cell dimensions } \\
\hline$a[\AA]$ & $8.9236(5)$ & $8.5924(17)$ & $9.0054(4)$ \\
\hline$b[\AA]$ & $8.7861(4)$ & $12.938(3)$ & $8.7908(4)$ \\
\hline$c[\AA]$ & $19.7125(10)$ & $14.250(3)$ & $19.4618(9)$ \\
\hline$\beta\left[^{\circ}\right]$ & $102.535(3)$ & 90 & $102.377(3)$ \\
\hline Volume $\left[\AA^{3}\right]$ & $1508.69(13)$ & 1584.1(6) & $1504.88(12)$ \\
\hline$Z$ & 4 & 4 & 4 \\
\hline$\rho$ (calc.) $\left[\mathrm{g} \mathrm{cm}^{-3}\right]$ & 1.0977 & 1.0455 & 1.191 \\
\hline$\mu\left[\mathrm{mm}^{-1}\right]$ & 0.072 & 0.069 & 0.249 \\
\hline $2 \theta$ range $\left[{ }^{\circ}\right]$ & 8.42 to 56.80 & 9.74 to 55.10 & 6.31 to 55.16 \\
\hline Parameters/restraints & $207 / 30$ & $218 / 30$ & $222 / 18$ \\
\hline Collected reflections & 22042 & 22986 & 10105 \\
\hline $\begin{array}{l}\text { Independent } \\
\text { reflections }\end{array}$ & 3457 & 3584 & 3348 \\
\hline$R$ (int.) & 0.1127 & 0.0517 & 0.0294 \\
\hline GOOF & 1.032 & 1.091 & 1.029 \\
\hline$R$ & 0.0681 & 0.0558 & 0.0551 \\
\hline$R_{\mathrm{W}}$ & 0.1490 & 0.1151 & 0.1469 \\
\hline
\end{tabular}

${ }^{a}$ Numbers in parentheses are std. deviations.

characteristics of those attached moieties, and will be discussed as follows. For these three structures, there are clear hydrogen bond interactions between $\mathrm{O} 1-\mathrm{H} 1 \mathrm{a} \cdots \mathrm{O} 2-\mathrm{C} 7$, the former

Table 4 Structural X-ray data for $\mathrm{VA}_{2}, \mathrm{VA}_{3}$ and $\mathrm{VA}_{6}{ }^{a}$

\begin{tabular}{|c|c|c|c|}
\hline Compound & $\mathbf{V A}_{2}$ & $\mathbf{V A}_{3}$ & $\mathbf{V A}_{6}$ \\
\hline \multicolumn{4}{|c|}{ Bonding distances $(\AA \mathbf{A})$} \\
\hline O1-H1a & $0.91(3)$ & $0.99(4)$ & $0.67(3)$ \\
\hline $\mathrm{O} 2 \cdots \mathrm{H} 1 \mathrm{a}$ & $1.75(3)$ & $1.68(4)$ & $2.01(3)$ \\
\hline N1-H1 & $0.83(2)$ & $0.83(3)$ & $0.82(2)$ \\
\hline $\mathrm{C} 7=\mathrm{O} 2$ & $1.247(2)$ & $1.246(3)$ & $1.247(2)$ \\
\hline C7-N1 & $1.338(3)$ & $1.331(3)$ & $1.335(2)$ \\
\hline $\mathrm{N} 1-\mathrm{C} 2$ & $1.429(3)$ & $1.424(3)$ & $1.426(2)$ \\
\hline $\mathrm{C} 2-\mathrm{C} 1$ & $1.392(3)$ & $1.388(4)$ & $1.392(2)$ \\
\hline $\mathrm{C} 1-\mathrm{O} 1$ & $1.362(3)$ & $1.364(3)$ & $1.356(2)$ \\
\hline \multicolumn{4}{|l|}{ Bonding angles $\left({ }^{\circ}\right)$} \\
\hline $\mathrm{O} 2-\mathrm{C} 7-\mathrm{N} 1$ & $122.0(2)$ & $121.9(2)$ & $121.76(15)$ \\
\hline $\mathrm{C} 7-\mathrm{N} 1-\mathrm{C} 2$ & $127.56(19)$ & $127.6(2)$ & $127.13(15)$ \\
\hline $\mathrm{N} 1-\mathrm{C} 2-\mathrm{C} 1$ & $123.4(2)$ & $123.3(2)$ & $123.45(16)$ \\
\hline $\mathrm{C} 2-\mathrm{C} 1-\mathrm{O} 1$ & $123.4(2)$ & $122.9(2)$ & $123.60(16)$ \\
\hline $\mathrm{H} 1 \mathrm{a}-\mathrm{O} 1-\mathrm{C} 1$ & $105.7(18)$ & $105.0(2)$ & $107(2)$ \\
\hline $\mathrm{H} 1-\mathrm{N} 1-\mathrm{C} 2$ & $115.7(13)$ & $112.8(18)$ & $116.2(14)$ \\
\hline $\mathrm{O} 1-\mathrm{H} 1 \mathrm{a} \cdots \mathrm{O} 2$ & $160(3)$ & $158(4)$ & $160(3)$ \\
\hline \multicolumn{4}{|c|}{ Dihedral angles $\left({ }^{\circ}\right)$} \\
\hline $\mathrm{H} 1 \mathrm{a}-\mathrm{O} 1-\mathrm{C} 1-\mathrm{C} 2$ & $-33.2(18)$ & $-39(3)$ & $-36(3)$ \\
\hline $\mathrm{O} 1-\mathrm{H} 1 \mathrm{a} \cdots \mathrm{O} 2-\mathrm{C} 7$ & $65(7)$ & 41 (11) & $58(9)$ \\
\hline $\mathrm{H} 1-\mathrm{N} 1-\mathrm{C} 2-\mathrm{C} 1$ & $-148.6(15)$ & $-144.9(19)$ & $-148.8(15)$ \\
\hline $\mathrm{H} 1-\mathrm{N} 1-\mathrm{C} 7-\mathrm{O} 2$ & $-176.2(15)$ & $-173(2)$ & $-175.8(15)$ \\
\hline $\mathrm{N} 1-\mathrm{C} 7-\mathrm{O} 2-\mathrm{C} 8$ & $178.5(4)$ & $-179.0(4)$ & $178.4(4)$ \\
\hline C1-C2-N1-C7 & $45.4(3)$ & $44.3(4)$ & $46.8(3)$ \\
\hline
\end{tabular}

${ }^{a}$ Numbers in parentheses are std. deviations.

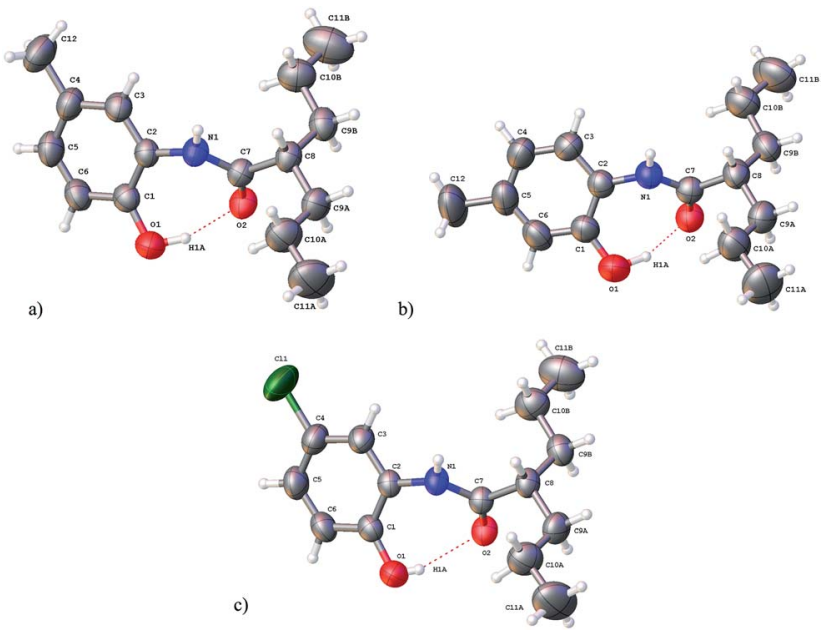

Fig. 1 X-ray diffraction structures for (a) $V_{2}$, (b) $V A_{3}$ and (c) $V_{6}$ (ellipsoids at $50 \%$ of probability).

belonging to the phenol and the latter being the carbonyl fragment, with bond distances of $1.75,1.68$ and $2.01 \AA$, where these values are smaller than the sum of the van der Waals radii (1.2 A for hydrogen and $1.52 \AA$ for oxygen). ${ }^{26}$ The bonding angles $(\mathrm{O} 1-\mathrm{H} 1 \mathrm{a} \cdots \mathrm{O} 2)$ for this same interaction are 160,158 and $160^{\circ}$, tending towards $180^{\circ}$ due to the strong directionality between these two fragments. Meanwhile, the torsion angles (O1-H1a $\cdots$ O2-C7) present for this hydrogen bond are 65,41 and $58^{\circ}$, evidencing a needed angularity to avoid steric hindrance between the aminophenol and valproyl moieties. This finding of hydrogen bonding correlates with the observation in the FTIR spectra, where four amidic bands instead of only two were identified, as is common in simpler amides. One pair may be due to the non-hydrogen bonded structure and the other may be due to the hydrogen-bonded counterpart.

For the covalent behaviour of the structures, the bond distances of O1-H1a and N1-H1 were 0.91, 0.99 and $0.67 \AA$ for the former, and $0.83,0.83$ and $0.82 \AA$ for the latter, showing bond contractions only for $\mathbf{V A}_{\mathbf{6}}$. In all cases, the double bonds between $\mathrm{C} 7$ and $\mathrm{O} 2$ are practically the same at 1.247, 1.246 and $1.247 \AA$ A, evidencing a negligible substituent effect through the structure. This last observation is reinforced, as $\mathrm{C} 7-\mathrm{N} 1$ also remains almost constant at $1.338,1.331$ and $1.35 \AA$ for these compounds. As examples of the general structural behaviour, the remaining bond distances, bond angles and torsion angles almost behave the same for the amidic junction between VPA and $\mathrm{OAMPOH}$. In particular, the amidic fragment is practically planar with dihedral angles for N1-C7-O2-C8 of 178.5, 179.0 and $178.4^{\circ}$. Meanwhile, the dihedral angles for the C1-C2-N1$\mathrm{C} 7$ fragment are $45.4,44.3$ and $46.8^{\circ}$, clearly tending to minimize the steric hindrance among the VPA and $\mathrm{OAMPOH}$ moieties.

\section{Cell viability of $\mathrm{VA}_{1-7}$}

For the cell viability tests, all the $\mathbf{V A}_{\mathbf{1 - 7}}$ compounds were predissolved in TWEEN 80 in $1: 9(\mathrm{w} / \mathrm{w})$ ratios. This mixture was 
reformulated using $1: 11(\mathrm{v} / \mathrm{v})$ TWEEN 80/DMSO ratios due to the hydrophobicity of these derivatives, and the final concentrations were related to the respective VA compound. According to the employed ratios of TWEEN 80 and DMSO, the tested concentrations were below the toxicity levels stated for these substances in cell viability assays, and blank tests were also carried out. ${ }^{27,28}$ At the tested concentrations there were no toxic effects. For VPA and all $\mathbf{V A}_{\mathbf{1 - 7}}$ compounds, their cell viabilities in C6 (rat glioma) and U373 (human glioblastoma) lines were measured. The results show that all VA compounds presented more activity than VPA (see Table 5), hence indicating that the molecular design of these derivatives was clever in generating new molecules that fulfilled the desired goal. The cell viability of VPA was measured as the control, and the inhibitory concentration at $50 \%\left(\mathrm{IC}_{50}\right)$ obtained for C6 cells $(1179 \pm 130.8 \mu \mathrm{M})$ and for U373 cells $(936.5 \pm 174.4 \mu \mathrm{M})$ was similar to that of previous reports, ${ }^{29}$ requiring a millimolar concentration for $48 \mathrm{~h}$. Meanwhile, for the $\mathbf{V A}_{\mathbf{1 - 7}}$ compounds, the required concentrations to achieve $\mathrm{IC}_{50}$ ranged from 19.7 to $74.8 \mu \mathrm{M}$ for C6, and 1.5 to $212.8 \mu \mathrm{M}$ for U373 cells, which is comparable with other designed compounds aimed for cancer treatment. ${ }^{30}$

\section{Structure activity analysis of $\mathbf{V A}_{\mathbf{1 -}}$}

$\mathbf{V A}_{\mathbf{1}}$ is the base compound and it was found to be 15.8 times more active than VPA in C6 cells $(74.8 \pm 8.4 \mu \mathrm{M})$ and 4.4 times more active than VPA in U373 cells $(212.8 \pm 12.3 \mu \mathrm{M})$, in the same range as other VPA amidic derivatives. ${ }^{31}$ In this case the molecular design gained credibility, due to the fact that this simple derivative augmented the biological response due to the recovery of the hydrogen-bonding group nearby, where it was originally placed in VPA. Furthermore, this modification not only recovers this interaction due to the presence of the aromatic ring, the biological effect is also enhanced by at least 4 times in U373 cells and almost 16 times in C6 cells. These results clearly show that the inclusion of an aromatic ring in this side of the parent molecule is a key method for developing other more potent derivatives. Therefore, the inclusion of steric and electronic modifiers of this aromatic ring, as is the case for $\mathbf{V A}_{2-7}$, should provide insight into the types of preferred interactions in a given molecular receptor in the cell. In this trend,

Table $5 \quad I C_{50}$ of $\mathrm{VA}_{1-7}$ measured by cell viability in glioma cell lines $\mathrm{C} 6$ and $\mathrm{U}_{373^{a}}$

\begin{tabular}{lllc}
\hline Compound & Substituent* & $\mathrm{C} 6(\mu \mathrm{M})$ & $\mathrm{U} 373(\mu \mathrm{M})$ \\
\hline $\mathbf{V A}_{\mathbf{1}}$ & $-\mathrm{H}$ & $74.8 \pm 8.4$ & $212.8 \pm 12.3$ \\
$\mathbf{V A}_{\mathbf{2}}$ & $m-\mathrm{Me}$ & $41.8 \pm 8.4$ & $151.8 \pm 14.4$ \\
$\mathbf{V A}_{\mathbf{3}}$ & $p-\mathrm{Me}$ & $55.8 \pm 11.0$ & $161.8 \pm 11.2$ \\
$\mathbf{V A}_{\mathbf{4}}$ & $m-\mathrm{NO}_{2}$ & $67.9 \pm 9.7$ & $64.9 \pm 9.0$ \\
$\mathbf{V A}_{\mathbf{5}}$ & $p-\mathrm{NO}_{2}$ & $45.3 \pm 12.3$ & $39.7 \pm 4.4$ \\
$\mathbf{V A}_{\mathbf{6}}$ & $m-\mathrm{Cl}$ & $19.7 \pm 4.7$ & $24.6 \pm 2.2$ \\
$\mathbf{V A}_{\mathbf{7}}$ & $p-\mathrm{Cl}$ & $21.8 \pm 2.7$ & $15.5 \pm 2.2$ \\
VPA & - & $1179 \pm 130.8$ & $936.5 \pm 174.4$
\end{tabular}

${ }^{a}$ Data represents median \pm standard error of at least three independent experiments. Glioma cells were in contact with each compound $\left(\mathbf{V A}_{\mathbf{1 - 7}}\right)$ in complete medium for $48 \mathrm{~h}$. *Position relative to the amidic group. the modification of the base compound $\mathbf{V A}_{\mathbf{1}}$ with an electrodonating -Me substituent in the meta or para position relative to the amide group indeed increased the cell viability of the base compound to $41.8 \pm 8.4 \mu \mathrm{M}$ for $\mathbf{V A}_{2}$ (28.2 times more activity than VPA) and $55.8 \pm 11.0 \mu \mathrm{M}(21.1$ times more activity than VPA) for $\mathbf{V A}_{3}$ in C6 cells. In U373 cells, $\mathbf{V A}_{\mathbf{2}}$ and $\mathbf{V A}_{\mathbf{3}}$ also showed an increased effect on cell viability $(151.8 \pm 14.4$ and $161.8 \pm$ $11.2 \mu \mathrm{M})$. This result clearly indicates that a bigger structure causes an important enhancement in the cell viability inhibition. Then, the compounds with an electro-withdrawing group, such as the $-\mathrm{NO}_{2}$ substituent at the meta or para position relative to the amide, presented a similar effect on the cell viability of $\mathbf{C} 6$ cells $\left(67.9 \pm 9.7 \mu \mathrm{M}\right.$ for $\mathbf{V A}_{4}$ and $45.3 \pm 12.3 \mu \mathrm{M}$ for $\left.\mathbf{V A}_{5}\right)$ as $\mathbf{V A}_{\mathbf{2}}$ and $\mathbf{V A}_{\mathbf{3}}$. The effect of these amides was more pronounced in U373 cells for the compounds with $-\mathrm{NO}_{2}(64.9 \pm 9.0 \mu \mathrm{M}$ for $\mathbf{V A}_{\mathbf{4}}$ and $39.7 \pm 4.4 \mu \mathbf{M}$ for $\mathbf{V A}_{\mathbf{5}}$ ). Finally, for both cell lines, $\mathbf{V A}_{\mathbf{6}}$ and $\mathbf{V A}_{\mathbf{7}}$ were the most active compounds. They contain $-\mathrm{Cl}$ as the substituent, behaving in a pi electro-donating/sigma electrowithdrawing manner, placed in the para or meta position relative to the amide. For $\mathrm{C} 6$ cells, the $\mathrm{IC}_{50}$ for $\mathbf{V A}_{\mathbf{6}}$ was $19.7 \pm 4.7$ $\mu \mathrm{M}$ and $21.8 \pm 2.7 \mu \mathrm{M}$ for $\mathbf{V A}_{7}$; in U373 cells, the doses to obtain the $\mathrm{IC}_{50}$ were $24.6 \pm 2.2 \mu \mathrm{M}$ for $\mathbf{V A}_{\mathbf{6}}$ and $15.5 \pm 2.2 \mu \mathrm{M}$ for $\mathbf{V A}_{\mathbf{7}}$. This is mainly due to the fact that a chlorine atom attached at an aromatic ring prevents a wide variety of chemical reactions, enhancing the possible interactions of the compound with biological receptors. ${ }^{32}$ Aromatic moieties possessing chlorine (and halogen substituents in general) are a key pharmacological feature ${ }^{15}$ justified because these fragments are present in an important amount of already tested and used pharmaceutical drugs and pesticides, and because of the plausible interactions that they present among them, such as $\mathrm{R}-\mathrm{Cl} \cdots \mathrm{C}=\mathrm{O}, \mathrm{R}-\mathrm{Cl} \cdots \mathrm{H}-$ $\mathrm{R}, \mathrm{R}-\mathrm{Cl} \cdots \mathrm{Ar}, \mathrm{R}-\mathrm{Cl} \cdots \mathrm{Cl}-\mathrm{R}$, etc.

Moreover, in order to track important physicochemical properties responsible for the biological findings, a semiempirical (Hyperchem v.8.0) partition coefficient $(\log P)$ calculation was developed. In this line, $\log P_{\mathrm{VPA}}$ was $2.61, \log P$ for $\mathbf{V A}_{\mathbf{1}}$ was 3.39, for $\mathbf{V A}_{\mathbf{2 - 3}}$ was 3.85 , for $\mathbf{V A}_{\mathbf{4 - 5}}$ was 3.34 and for $\mathbf{V} \mathbf{A}_{\mathbf{6}-\mathbf{7}}$ was 3.90. This calculation was carried out for each compound to track hydrophobic/hydrophilic ratios and correlate them with biologic trends. The results clearly evidence that the most hydrophobic ratio, resulting from the amide in $\mathbf{V A}_{\mathbf{6 - 7}}$, led to the most potent inhibition, and this was attained due to the $-\mathrm{Cl}$ substituent.

In general, $\mathbf{V A} \mathbf{A}_{\mathbf{1}}, \mathbf{V A}_{\mathbf{2}}$ and $\mathbf{V \mathbf { A } _ { 3 }}$ presented a greater effect on $\mathbf{C 6}$ cells than U373 cells, but $\mathbf{V A}_{\mathbf{4}} \mathbf{V} \mathbf{V A}_{\mathbf{5}}, \mathbf{V A}_{\mathbf{6}}$ and VPA required similar doses for the $\mathrm{IC}_{50}$. From the analysis of this data we can conclude that the new compounds not only maintain the effect of VPA on the cell viability, but can also achieve the same viability with lower doses. Related references clearly state that amides of VPA do not undergo hydrolysis ${ }^{33,34}$ or further biotransformations, due to the steric hindrance of the valproyl moiety not only under chemical but also biological conditions. Therefore, this kind of compound should have a major effect on cell viability due to the newly obtained chemical structure and not due to the VPA metabolite. This demonstrates that the new base structure (with the neutral substituent) can be modified to increase the activity, and the best activity was found with $-\mathrm{Cl}$, followed by $-\mathrm{NO}_{2}$ and 
finally with -Me in U373 cells. But in C6 cells, there was not a significant difference between $-\mathrm{NO}_{2}$ and $-\mathrm{Me}$ groups. This may reflect different histone deacetylase expression or regulation in these cell lines and further work is under development on this issue.

\section{Conclusions}

Finally, seven designed valproic acid derivatives, $\mathrm{N}$-(orthohydroxyphenyl)valproamides (VA-7), were obtained in moderate yields by coupling valproyl chloride with seven orthoaminophenols. This led to a family of amides with similar structural characteristics but tuneable electronic and steric contributions, through the inclusion of electro-donating $(-\mathrm{Me})$, electro-withdrawing $\left(-\mathrm{NO}_{2}\right)$ or pi electro-donating/sigma electro-withdrawing $(-\mathrm{Cl})$ substituents at the aromatic ring. The identity of such derivatives was evidenced through spectroscopic characterization using FTIR, ${ }^{1} \mathrm{H},{ }^{13} \mathrm{C}$ and HETCOR $\mathrm{NMR}$, as well as by melting point analysis. In particular, for three of the derivatives $\left(\mathbf{V A}_{\mathbf{2}}, \mathbf{V A}_{\mathbf{3}}\right.$ and $\mathbf{V A}_{\mathbf{6}}$ ) it was feasible to determine their chemical crystalline structures, in all cases behaving in a similar fashion and with very similar conformations independent of the attached substituents. In general, $\mathbf{V A}_{\mathbf{1}}$, $\mathbf{V A}_{2}$ and $\mathbf{V A}_{3}$ affected C6 cells more than U373 cells, but VA, $\mathbf{V A}_{5}, \mathbf{V A}_{6}$ and VPA required similar doses for the $\mathrm{IC}_{50}$. From the analysis of this data we can conclude that the new compounds not only maintain the effect of VPA on cell viability, but also require lower doses. This demonstrates that the new base structure (with a neutral substituent) can be modified to increase the activity, and the best activity was found with $-\mathrm{Cl}$, which was as expected due to the inclusion of this substituent in a huge amount of tested drugs. The hydrophobic effect was also an important variable in enhancing the potency of these derivatives, and the chlorine-bearing molecules produced the best results. In the biological trend $-\mathrm{Cl}$ is then followed by $-\mathrm{NO}_{2}$ and finally by -Me in U373 cells. However, in C6 cells, there was not a significant difference between the $-\mathrm{NO}_{2}$ and - Me groups, since they have almost the same hydrophobic/hydrophilic ratio according to the $\log P$ results. This may reflect different histone deacetylase expression or regulation in these cell lines, and work is under development on this issue. An important perspective is that $\mathbf{V A}_{\mathbf{6}}$ and $\mathbf{V A}_{\mathbf{7}}$ may become lead structures in the search for more potent pharmaceutical prototypes.

\section{Acknowledgements}

We acknowledge CONACyT projects 47310337 (L. Arregui) and 222872 (H. I. Beltrán), UAM and SEP-PROMEP for financial support. A. Alpuche-García and X. Dávila-González acknowledge university scholarships from CONACyT and UAM.

\section{References}

1 C. Wang, Z. Luan, Y. Yang, Z. Wang, Y. Cui and G. Gu, Neurosci. Lett., 2011, 497, 122-127.

2 S. Chateauvieux, F. Morceau, M. Dicato and M. Diederich, J. Biomed. Biotechnol., 2010, 2010, 479364.
3 R. W. Johnstone, Nat. Rev. Drug Discovery, 2002, 1, 287-299.

4 M. Dokmanovic, C. Clarke and P. A. Marks, Mol. Cancer Res., 2007, 5, 981-989.

5 D. Marchion and P. Münster, Expert Rev. Anticancer Ther., 2007, 7, 583-598.

6 M. Mottamal, S. Zheng, T. L. Huang and G. Wang, Molecules, 2015, 20, 3898-3941.

7 A. V. Krauze, S. D. Myrehaug, M. G. Chang, D. J. Holdford, S. Smith, J. Shih, P. J. Tofilon, H. A. Fine and K. Camphausen, Int. J. Radiat. Oncol., Biol., Phys., 2015, 92, 986-992.

8 D. Thotala, R. M. Karvas, J. A. Engelbach, J. R. Garbow, A. N. Hallahan, T. A. DeWees, A. Laszlo and D. E. Hallahan, Oncotarget, 2015, vol. 6, pp. 35004-35022.

9 S. Eyal, B. Yagen, J. Shimshoni and M. Bialer, Biochem. Pharmacol., 2005, 69, 1501-1508.

10 H. Deubzer, B. Busche, G. Rönndahl, D. Eikel, M. Michaelis, J. Cinatl, S. Schulze, H. Nau and O. Witt, Leuk. Res., 2006, 30, 1167-1175.

11 G. G. Mackenzie, L. Huang, N. Alston, N. Ouyang, K. Vrankova, G. Mattheolabakis, P. P. Constantinides and B. Rigas, PLoS One, 2013, 8, e61532.

12 C. Harmon and D. Myles, Valproic acid salts, US Pat., WO2009142968 A2, 2009.

13 N. Tarasenko, S. M. Cutts, D. R. Phillips, G. Berkovitch-Luria, E. Bardugo-Nissim, M. Weitman, A. Nudelman and A. Rephaeli, Biochem. Pharmacol., 2014, 88, 158-168.

14 E. Perrino, G. Cappelletti, V. Tazzari, E. Giavini, P. D. Soldato and A. Sparatore, Bioorg. Med. Chem. Lett., 2008, 18, 18931897.

15 C. Bissantz, B. Kuhn and M. Stahl, J. Med. Chem., 2010, 53, 5061-5084.

16 G. M. Sheldrick, Acta Crystallogr., Sect. C: Struct. Chem., 2015, 71, 3-8.

17 O. V. Dolomanov, L. J. Bourhis, R. J. Gildea, J. A. K. Howard and H. Puschmann, J. Appl. Crystallogr., 2009, 42, 339-341.

18 E. Bechar and H. Astroug, Arch. Pharm., 1997, 330, 273-276.

19 N. Pariente-Cohen, M. Weitman, N. Tania, D. T. Major, H. E. Gottlieb, S. Hoz and A. Nudelman, RSC Adv., 2015, 5, 24038-24043.

20 C. U. Johannessen and S. I. Johannessen, CNS Drug Rev., 2003, 9, 199-216.

21 H. Andleeb, Y. Tehseen, S. J. Ali Shah, I. Khan, J. Iqbal and S. Hameed, RSC Adv., 2016, 6, 77688-77700.

22 Y. Yamazaki, T. Toma, M. Nishikawa, H. Ozawa, A. Okuda, K. Abe and S. Oda, Benzoxazole compound and pharmaceutical composition containing the compound, Germany Pat., EP1433786 B1, 2011.

23 M. Casado Centellas, B. R. Insa, B. N. Reig and B. N. Gavaldà, New therapy for transthyretin-associated amyloidosis, Spain Pat., WO2013060668 A1, 2013.

24 J. A. Clements, R. C. Heading, W. S. Nimmo and L. F. Prescott, Clin. Pharmacol. Ther. Pediatr. Perspect., 1978, 24, 420-431.

25 J. Fu, K. Cheng, Z. M. Zhang, R. Q. Fang and H. L. Zhu, Eur. J. Med. Chem., 2010, 45, 2638-2643.

26 A. Bondi, J. Phys. Chem., 1964, 68, 441-451. 
27 B. Arechabala, C. Coiffard, P. Rivalland, L. J. M. Coiffard and Y. D. Roeck-Holtzhauer, J. Appl. Toxicol., 1999, 19, 163-165. 28 Y. He, H. Liu, Z. Xie, Q. Liao, X. Lai and Z. Du, Drug Dev. Ind. Pharm., 2014, 40, 237-243.

29 J. A. Benitez, L. Arregui, G. Cabrera and J. Segovia, Neuroscience, 2008, 156, 911-920.

30 V. Di Bussolo, E. C. Calvaresi, C. Granchi, L. Del Bino, I. Frau, M. C. Dasso Lang, T. Tuccinardi, M. Macchia, A. Martinelli, P. J. Hergenrother and F. Minutolo, RSC Adv., 2015, 5, 1994419954.
31 M. Farooq, A. El-Faham, S. N. Khattab, A. M. Elkayal, M. F. Ibrahim, N. A. Taha, A. Baabbad, M. A. M. Wadaan and E. A. Hamed, Asian Pac. J. Cancer Prev., 2014, 15, 77857792 .

32 H. Marquardt, Angew. Chem., 1995, 107, 1017.

33 M. Bialer, A. Haj-Yehia, K. Badir and S. Hadad, Pharm. World Sci., 1994, 16, 2-6.

34 S. Blotnik, F. Bergman and M. Bialer, Drug Metab. Dispos., 1996, 24, 560-564. 